\title{
Effect of Jointworms on the Growth and Reproduction of Four Native Range Grasses of Idaho
}

BRIAN M. SPEARS AND WILLIAM F. BARR

\begin{abstract}
A study of jointworm larvae (Tetramesa Walk.) feeding in 4 native range grasses of Idaho was conducted to determine effects on their hosts. These insects were responsible for a decrease in the length of reproductive culms of red threeawn (Aristida longiseta Steud.), bottlebrush squirreltail (Sitanion hystrix (Nutt.) J.G. Smith), sand dropseed (Sporobolus cryptandrus (Torr.) A. Gray), and needleandthread (Stipa comata Trin. and Rupr.) Jointworms caused a decrease in the number of spikelets produced per inflorescence in bottlebush squirreltail and needleandthread, and a decrease in the inflorescence length of sand dropseed. They caused a decrease in seed weight, percentage germination, and germination rate of all 4 grasses. By adversely affecting native grasses, these insects contribute significantly to the degradation of valuable rangelands, and their control may be desirable.
\end{abstract}

Many native grasses are important components of Idaho's rangeland. Sharp and Sanders (1978) reported that 7.5 million ha in Idaho are covered with sagebrush-grass vegetation and 485.6 thousand ha are covered with bunchgrass vegetation. This totals about $40 \%$ of Idaho's land area. Other vegetation types support valuable grasses also. Domestic livestock graze at least $65 \%$ of Idaho's total land area (Sharp and Sanders 1978). Native grasses are valuable as forage and cover for wild life. As part of the ecological community, native grasses are of special significance in building and maintaining watershed stability. Consequently, any insects feeding on these grasses are potentially of economic importance since they may adversely affect their growth and reproduction.

Larvae of the genus Tetramesa Walk. (Hymenoptera: Eurytomidae), commonly called jointworms or strawworms, are often found in culms of many grass species. Peck (1951) listed 65 North American species of jointworms, and Claridge (1961) listed 33 palaearctic species. These insects are generally host-specific (Claridge 1961). Jointworms attacking small grains decrease grain production (Webster and Reeves 1909, Doane 1916, Phillips and Poos 1918, revised 1940, Knowlton and Janes 1933, Chamberlain 1941, and Sterling and Maclaren 1964).

Chamberlain (1941) reported that burning was an effective control measure for $T$. tritici (Fitch), a gall-forming pest of wheat. However, Webster and Reeves (1909) stated that burning was an impractical control measure for $T$. grandis (Riley), which bores internally in the nodes of wheat. Here, the nodes containing jointworms retained a high moisture content and would not burn. Phillips (1920) thought that clipping cultivated grasses in the spring would delay production of reproductive culms, resulting in no oviposition sites for jointworm adults. He also reported that $T$. poae (Phillips and Emery), attacking Kentucky bluegrass (Poa pratensis L.) had little chance to breed in pastures kept closely grazed by livestock. Infestations occurred only where the host was protected from grazing.

Hewitt et al. (1974) reported that little information was available

\footnotetext{
Authors are range conservationist, Bureau of Indian Affairs, Warm Springs Agency, Warm Springs, Ore. 9776I; and professor emeritus, Department of Entomology, Plant, and Soil Sciences, University of Idaho, Moscow 83843.

Manuscript accepted March 26, 1984.
}

for the economic importance of these insects on range grasses. Therefore, this study was conducted to determine the effects of joint worms on the growth and reproduction of Idaho native range grasses.

\section{Methods}

The effects of jointworms on 4 host bunchgrasses were studied. The grasses were: (1) red threeawn (Aristida longiseta Steud.), (2) sand dropseed (Sporobolus cryptandrus (Torr.) A. Gray), (3) bottlebrush squirreltail (Sitanion hystrix (Nutt.) J.G. Smith), and (4) needleandthread (Stipa comata Trin. and Rupr.). The study site of the first 2 grasses was $0.8 \mathrm{~km} \mathrm{~N}$ of Slate Creek, Idaho Co., Ida., and that of the latter 2 was $10.5 \mathrm{~km} \mathrm{SE}$ of Boise, Ada Co., Ida. These grasses and their locations were selected for study because of current high population-intensities of jointworms.

The insects involved were identified only to genus because current taxonomic information for making species identification has not yet been developed for jointworm larvae. However, the larvae in each grass were believed to be different species because: (1) jointworms are generally host-specific, and the grasses were members of different tribes; and (2) they damaged the grasses in different ways. Jointworms in red threeawn and sand dropseed bored in the center of culms just above the nodes, those in bottlebrush squirreltail formed shallow galls within culm walls, and those in needleandthread occupied cells formed end-to-end in the center of culms. Therefore, the jointworms affecting each grass will be treated and discussed as separate species in this paper.

Vigorous bunches were selected as the experimental material for all 4 grasses to insure healthy, homogeneous material. Three replicates for each species-treatment combination were randomly identified in the field. All culms from the previous growing season were clipped at the base for both treatment and control plants. The clipped culms were removed from control plants (uninfested), but were left standing in the treated (infested) plants. Additional infested culms were added to infested plants to insure high populations of jointworms. Each treatment and each control bunch was individually caged to: (1) prevent adult joint worms emerging from the uncaged neighboring plants not used as study material from ovipositing in controls, and (2) to insure that jointworms emerging in treatments would remain there to oviposit in developing culms.

The cages were removed from all bunches following oviposition. The bunches were allowed to mature, and then taken to the laboratory for analysis. All stems were dissected to confirm the presence of jointworm larvae in the treatments, and the absence of jointworm larvae in the controls. The number of larvae per infested culm in treatments varied from 1 to 2 with a mean of 1.1 in red threeawn, 1 to 16 with a mean of 5.5 in bottlebush squirreltail, 1 to 3 with a mean of 1.4 in sand dropseed, and 1 to 15 with a mean of 5.4 in needleandthread.

The following measurements were made for the total number of stems and leaves contained in the bunches up to a sample size of 75 per treatment per species: (1) length of reproductive culms $(\mathrm{cm}),(2)$ length $(\mathrm{cm})$ of the innovative leaves (length $(\mathrm{cm})$ of the basal leaves 
on the reproductive culms for sand dropseed), and (3) number of spikelets in the inflorescence (inflorescence length (cm) for sand dropseed). Differences between means were determined by t-tests for unequal sample size (Sokal and Rohlf 1969).

The seeds (inflorescences for sand dropseed) from reproductive culms were consolidated into lots for each bunch. The seeds (inflorescences for sand dropseed) in each lot were thoroughly mixed. Seed weight $(\mathrm{mg})$ per 25 seeds (per inflorescence for sand dropseed) was measured for each control and treatment ( 3 subsamples from 2 of the bunches and 4 from the third). The seeds were then refrigerated for $6 \mathrm{mo}$ at $1^{\circ} \mathrm{C}$ and then placed on damp filter paper in petri dishes ( 25 seeds per dish). The petri dishes were placed in a growth chamber at $25^{\circ} \mathrm{C}$ with a 16-hr day length. Percentage germination was measured. Germination rate was measured from the 25 -seed subsamples and converted to be expressed as seedlings day ${ }^{-1} 100$ seeds $s^{-1}$ (Maguire 1962). Differences between means for the above measurements were determined by t-tests (Sokal and Rohlf 1969).

This study was designed to show the effects of jointworms on grass culms they attack. The effect of these insects on a total grass population would be variable depending on the number of culms attacked. Previous measurements have indicated that populationintensities of jointworms vary from cases where no culms are attacked to cases where all culms are attacked, and also vary from year to year with the primary controlling factor being parisitization. The treatments in this study are representative of years in which high joint worm infestations occur. In years of lesser infestation, effects on attacked culms would be similar, but effects on the total population of a grass would be less.

\section{Results and Discussion}

The effects of jointworms on the growth and reproduction of their hosts were generally detrimental. However, the grasses were affected in different magnitudes (Table 1).

Jointworm attack reduced culm length $39 \%$ in red threeawn, $35 \%$ in sand dropseed, $55 \%$ in needleandthread, and $11 \%$ in bottlebrush squirreltail. The reduction was significant for all grasses tested.

Jointworms caused a $14 \%$ increase in leaf length of red threeawn, and an $8 \%$ increase in leaf length of needleandthread. They had no significant effect on leaf length of bottlebrush squirreltail, but caused an $8 \%$ decrease in leaf length of sand dropseed. However, sand dropseed had no innovative leaves, so the first basal leaf of the reproductive culms was measured. If further tests were conducted, it might be shown that jointworm feeding generally causes a slight but significant increase in the length of innovative leaves of most grasses and a slight decrease in the leaf length of reproductive culms. However, more study is necessary to establish this theory. In any case, the small increase in innovative leaf length shown statistically does not compensate for the decreased productivity of reproductive culms, or for the adverse effects of these insects on seed production.

Jointworms had a negative effect on the number of spikelets produced per inflorescence for 2 of the grasses studied. They caused a $44 \%$ decrease in the number of spikelets produced per inflorescence in bottlebrush squirreltail, and a $21 \%$ decrease in the number of spikelets produced per inflorescence in needleandthread. However, they had no effect on the number of spikelets produced per inflorescence in red threeawn. Jointworms reduced inflorescence length of sand dropseed $47 \%$.

The effects of jointworms on seed weight were greatest in needleandthread, which suffered a $60 \%$ reduction in seed weight. Seed weight was reduced $47 \%$ in red threeawn and $46 \%$ in sand dropseed. Seed weight of bottlebrush squirreltail was reduced $33 \%$.

The effect of jointworms on percentage germination was dramatic on red threeawn, in which a $99 \%$ reduction. was recorded. The effect was less for other grasses, but still considerable. Jointworms reduced percentage germination $59 \%$ in sand dropseed, $70 \%$ in bottlebrush squirreltail, and $54 \%$ in needleandthread.
Table 1. Mean length of reproductive culms (cm), length of the innovative leaves $(\mathrm{cm})^{4}$, number of spikelets per inflorescence ${ }^{2}$, seed weight ( $\mathrm{mg} 25$ seeds $\left.{ }^{-1}\right)^{3}$, percentage germination, and germination rate (seedling day ${ }^{-1}$ 100 seeds $^{-1}$ ) of jointworm-infested and jointworm-free culms from four grasses.

\begin{tabular}{lccc}
\hline Variable & $\begin{array}{c}\text { Jointworm- } \\
\text { infested }\end{array}$ & $\begin{array}{c}\text { Jointworm- } \\
\text { free }\end{array}$ & $\begin{array}{c}\text { Significance } \\
\text { level }\end{array}$ \\
\hline Culm length & & & \\
red threeawn & 31.0 & 50.7 & $P<0.01$ \\
bottlebrush squirreltail & 30.0 & 33.7 & $P<0.01$ \\
sand dropseed & 47.3 & 73.2 & $P<0.01$ \\
needleandthread & 34.7 & 76.3 & $P<0.01$ \\
Leaf length & & & \\
red threeawn & 39.7 & 34.8 & $P<0.01$ \\
bottlebrush squirreltail & 22.0 & 23.1 & $P<0.20$ \\
sand dropseed & 19.5 & 21.2 & $P<0.05$ \\
needleandthread & 34.5 & 31.8 & $P<0.01$ \\
Number of spikelets & & & \\
red threeawn & 17.0 & 17.0 & $P<1.00$ \\
bottlebrush squirreltail & 5.0 & 9.0 & $P<0.10$ \\
sand dropseed & 14.2 & 26.8 & $P<0.01$ \\
needleandthread & 16.1 & 20.3 & $P<0.01$ \\
Seed weight & & & \\
red threeawn & 63.6 & 120.4 & $P<0.01$ \\
bottlebrush squirreltail & 108.2 & 162.5 & $P<0.01$ \\
sand dropseed & 67.9 & 126.9 & $P<0.01$ \\
needleandthread & 48.4 & 121.2 & $P<0.01$ \\
Percentage germination & & & \\
red threeawn & 0.4 & 46.8 & $P<0.01$ \\
bottlebrush squirreltail & 20.0 & 66.0 & $P<0.01$ \\
sand dropseed & 13.6 & 32.8 & $P<0.10$ \\
needleandthread & 2.4 & 5.2 & $P<0.10$ \\
Germination rate & & & \\
red threeawn & 0.1 & 4.6 & $P<0.01$ \\
bottlebrush squirreltail & 2.8 & 7.8 & $P<0.01$ \\
sand dropseed & 0.4 & 1.1 & $P<0.10$ \\
needleandthread & 0.1 & 0.2 & $P<0.10$ \\
\hline
\end{tabular}

'First basal leaf of reproductive culms for sand dropseed. 'Inflorescence length for sand dropseed.

3Seed weight per inflorescence for sand dropseed.

Percentage germination was low for both the treatment and control of needleandthread. Some factor was apparently causing many seeds which appeared viable to remain dormant. If they were viable, and dormancy was terminated, a much higher percentage germination would be expected in the abscence of insect damage since the seeds from these plants contained a higher amount of heavier seeds than plants damaged by jointworms. However, more study is necessary to conform this observation.

The effect of jointworms on germination rate was also dramatic. They reduced germination rate of seeds $98 \%$ in red threeawn, $64 \%$ in bottlebrush squirreltail and sand dropseed, and $50 \%$ in needleandthread. Maguire (1962) reported that germination rate provided a means for evaluating the effects of seed size upon seedling vigor. Based on this observation, one would expect a decrease in emergence of seedlings from smaller seeds with low germination rates resulting from jointworm damage.

Since these insects are detrimental to native grasses which are major components of rangeland vegetation, they contribute significantly to the degradation of valuable rangelands. Therefore, their control would be desirable in most instances. Chemical control of jointworms would be difficult because adults are short-lived, small, and difficult to distinguish from other small Eurytomidae. Larvae could be controlled only with systemics since they live internally in grass culms. Cultural control would be more feasible. Two tools that can be relatively easily manipulated, are compatible with 
livestock management, and which may effectively control jointworms are burning and grazing.

As a group, these insects are very complex from a bionomic standpoint. It is assumed that all species decrease plant productivity, but all species of jointworms and the host(s) each attack need to be studied individually since these insects are generally hostspecific and each grass is affected differently. Also, intensive study of each jointworm and its host(s) would reveal more about its life-cycle, natural controlling factors, and population fluctuations. This information would contribute to the development of satisfactory controli measures.

A positive aspect of the detrimental effects of these insects on grasses should not be overlooked. This is in cases where undesirable grasses are attacked by jointworms. Under these circumstances, one may want to enhance or introduce jointworms to increase their populations as an aide for controlling undesirable grasses.

\section{Conclusions}

The effects of jointworms on their hosts were greatly detrimental. The greatest detriment of their attack was to reproductive potential of the grasses as evidenced by reduction in seed weight, percentage germination, and germination rate. The only beneficial aspect was a slight increase in the length of innovative leaves. However, this does not compensate for the decrease in the length of reproductive culms, or for the damage to seed prodaction and viability. Since these insects are detrimental to range grasses, their control would be desirable. More study is necessary for developing control measures.

\section{Literature Cited}

Chamberlain, T.R. 1941. The wheat jointworm in Oregon, with special reference to its dispersion, injury, and parasitization. USDA Tech. Bull. 784:1-47.

\section{GRADUATE RESEARCH ASSISTANT}

Department of Animal, Dairy and Veterinary Science

\section{UTAH STATE.UNIVERSITY}

Master's level halftime. Work on nutrition and feeding behavior of cattle and sheep on mountain range in Southern Utah. Live in Cedar City during the summer months. Requires B.S. in Animal Science, Range Science or related discipline. Position available June 1985 . Contact:

Richard L. Senft

Department of Animal,

Dairy and Veterinary Science

UTAH STATE UNIVERSITY, UMC 48

Logan, Utah 84322

(801) $750-2158$

An Affirmative Action/Equal Opportunity Employer
Claridge, M.F. 1961. A contribution to the biology and taxonomy of some palaearctic species of Tetramesa Walker (=Isosoma Walk.; =Harmolita Motsch.) (Hymenoptera: Eurytomidae), with particular reference to the British fauna. Trans. Roy. Entomol. Soc. London. 113:175-217.

Doane, R.W. 1916. The wheat strawworm. California State Com. Hort. Monthly Bull. 5:69-72.

Hewitt, G.B., E.W. Huddleston, R.J. Lavione, D.N. Ueckert, and J.G. Watts., 1974. Rangeland Entomology. Soc. Range Manage., Denver, Colo.

Inowlton, G.F., and M.J. Janes. 1933. Distribution and damage by jointworm flies in Utah. Utah Agr. Exp. Sta..Bull. 243.

Maguire, J.D. 1962. Speed of germination - aid in selection and evaluation of seedling omergence and vigor. Crop Sci. 2:176-177.

Peck, 0. 1951. Family Eurytomidae. p. 568-583. In: Hymenoptera of America North of Mexico Synoptic Cataglog. Agr. Mono. No. 2. U.S. Government Printing Office, Washington, D.C.

Phillips, W.J. 1920. Studies on the life history and habits of jointworm flies of the genus Harmolita (Isosoma) with recommendations for control, USDA Bull. 808.

Phillips, W.J., and W.F. Poos. 1918 (revised 1940). The wheat jointworm and its control. USDA Farm Bull. 1006.

Sharp, L.A., and K.D. Sanders. 1978. Idaho rangeland development and improvement: a summary. Univ. of Idaho Forest, Wildlife, and Range Exp. Sta. Contrib. No. 112.

Sokal, R.R., and F.J. Rohlf. 1969. Introduction to Biostatistics. William Freeman and Co., San Francisco.

Sterling, J.D.E., and R.B. Maelaren. 1964. A greenhouse method of rearing the barley jointworm, Tetramesa hordei, with observations on the biology and host-plant relations of the insect. Can. J. Plant Sci. 44:53-56.

Webster, F.M., and G.I. Reeves. 1909. The wheat strawworm. USDA Bur. Entomol. Cir. 106.

\section{GRADUATE RESEARCH ASSISTANT}

Department of Animal, Dairy and

Veterinary Science

\section{UTAH STATE UNIVERSITY}

Masters or PhD level, half-time. Develop computer simulation models of range livestock production systems. Requires B.S. or M.S. in Animal Science, Range Science or related discipline. Position begins immediately.

Contact:

Richard L. Senft

Department of Animal, Dairy and Veterinary Science

UTAH STATE UNIVERSITY, UMC 48

Logan, Utah 84322

(801) 750-2158

An Affirmative Action/Equal Opportunity Employer 